\title{
JOURNAL.RU
}

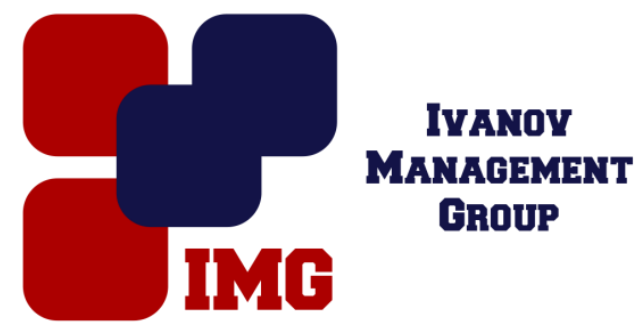

Дергунов С.А., Макаева А.А., Тарановская Е.А., Гончаров В.О. Оренбургский государственный университет Оренбург, Россия

doi: 10.18411/1j-31-05-2017-71

idsp 000001:1j-31-05-2017-71

\section{Производство и применение сероасфальтобетонных покрытий на автомобильных дорогах и мостах}

\section{Аннотация}

Актуальным направлением в современном дорожном материаловедении является разработка новых долговечных асфальтобетонов с добавкой серы. Доказано, что сероасфальтобетон устойчив к воздействиям механических нагрузок и погодно-климатическим условиям.Втакого рода композитах сера выполняет роль связки между битумом и щебнем, повышая адгезионные свойствараспределенно с положительно и отрицательно заряженными микрочастицами зерен, что позволяет отказаться от поверхностно-активных веществ.

Ключевые слова: автомобильная дорога,битум, дорожное покрытие, сероасфальтобетон, долговечность.

Как показывает практика, в России асфальтобетонные покрытия быстро деформируются и разрушаются раньше гарантийного срока и требуют ремонта уже после первых лет эксплуатации. К причинам преждевременных разрушений и деформаций относятся: высокая интенсивность движения, увеличение осевых нагрузок, нарушение технологии и производства строительства, а также низкое качество используемых материалов. Анализ состояния покрытия проезжей части улично-дорожной сети показывает, что для достижения прогресса в области строительства и эксплуатации,автомобильных дорог необходимо уделить особое внимание разработке новых инновационных типов асфальтобетонов и 
технологии их изготовления. Это позволит существенно повысить эксплуатационные показатели дорожных покрытий и срок их службы[1].

Одним из перспективных направлений повышения долговечности и транспортно-эксплуатационных показателей автомобильных дорог является применение асфальтобетонных смесей на основе битумного вяжущего модифицированного оптимальным содержанием серы.

Преимущество добавкизаключается в том, что этот продукт выгоден, как с экономической, так и с экологической точек зрения. Применение асфальтобетонов с добавкой серы позволяет улучшить качество дорожных асфальтобетонов, т.кона выполняет роль связки между битумом и щебнем, обладает высокими адгезионными свойствами с положительно и отрицательно заряженными микрочастицами зерен, за счет чего повышает адгезионные свойства между битумом и щебнем[2].Опытное применение сероасфальтобетонных смесей позволяет утверждать, что их использование обеспечивает повышение качества дорожного покрытия за счёт обеспечения стойкости к колееобразованию (на 20-30\%), к износу (на 25-40\%), трещиностойкости (на 10-25\%). Снижает расход битума в составе асфальтобетонной смеси на 15\%, энергозатраты при производстве асфальтобетонных смесей на $10-15 \%$ за счёт понижения технологических температур производства, транспортирования, укладки и уплотнения смесей[3].Процесс производства сероасфальтобетона похож на «обычный» асфальтобетон. Он не требует никаких дополнительных затрат и технологий при изготовлении и укладке в покрытия дорог: приготавливается традиционными способами и уплотняется обычными асфальтоукладчиками и катками (рис.1) [4].

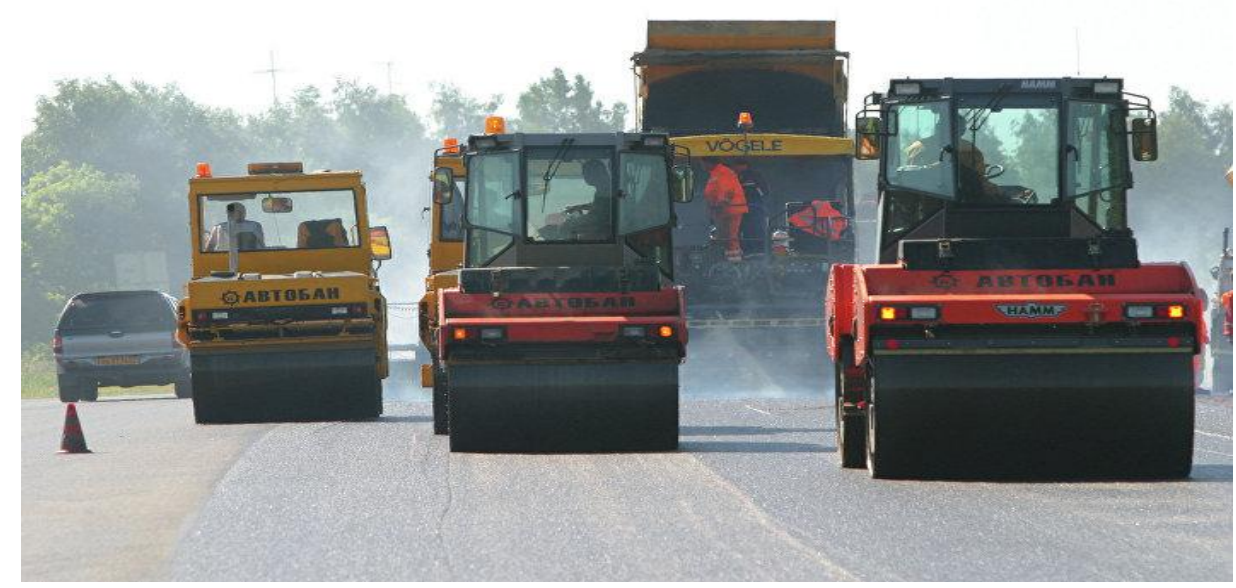

Рисунок-1 Укладка сероасфальтобетона 
Расчет содержания вяжущего в сероасфальтобетонной смеси проводился согласно разработанной методике, в основу которой положено равенство объемов нефтяного битума базового состава асфальтобетона и вяжущей композиции, содержащей битум и серный модификатор.Разработанный состав литой сероасфальтобетонной смеси приготавливали в лабораторных условиях в соответствии с СТО 5718-001-66921180 представленв таблице 1.

Таблийа 1

Состав минеральных составляющих литого сероасфальтобетона.

\begin{tabular}{|c|c|c|c|c|c|}
\hline \multicolumn{5}{|c|}{ Состав, \% } \\
\hline Щебень & Отсев & Песок & Битум & Сера & Минеральный порошок \\
\hline 47,0 & 0,0 & 36,0 & 6,5 & 4,5 & 24,0 \\
\hline
\end{tabular}

При приготовлении смесей в лаборатории по горячей технологии сначала минеральные материалы (щебень, песок, минеральный порошок) предварительно высушивали, а битум обезвоживали. Смесь литого сероасфальтобетона готовилась в специальном лабораторном смесителе. Минеральные материалы в количествах, заданных по составу, отвешивали в емкость, нагревали, периодически помешивая, до температуры $145-160^{\circ} \mathrm{C}$ и добавляли требуемое количество не нагретого минерального порошка, серы и нагретого в отдельной емкости вяжущего.

Представленный материал применен на экспериментальных участках Оренбургской области и мониторился в течении 2-х лет[5,6].

Наблюдение показывает, что покрытие характеризуется высокими и стабильными показателями ровности, на нем не образовались трещины, наплывы, волны и колея. Отличительными особенностями сталиего специфические транспортно-эксплуатационные показатели, включая комфортабельные и безопасные ездовые качества, сопротивляемость внешним воздействиям, стабильность и долговечность слоя, тем самым способствуя решению одной из самых актуальных проблем в области дорожного строительства. 
1. Перспективы развития инновационной деятельности в дорожном хозяйстве / Кочетков А.В., Янковский Л.В. // Инновационный транспорт. 2014. №1 (11). С. 42-45.

2. Гурарий Е.М. Влияние серы на структурообразование в битумах// Тр. СоюзДорНИИ. 1971. Вып.44. 137 с.

3. Фомин А.Ю., Хозин В.Г. Применение серы в производстве дорожно- строительных материалов // Строительные материалы. 2009. № 11. С. 20-22.

4. Василовская Г.В., Назиров Д.Р. Сероасфальтобетон // Журнал Сибирского федерального университета. Серия: Техника и технологии. 2011. Т. 4. № 6. С. 696-703.

5. ТУ 5718-002-53737504-01. Смеси сероасфальтобетонные и литой сероасфальтобетон.

6. Официальный сайт главного управления дорожного хозяйства Оренбургской области. Электронный ресурс: точка доступа http://www.orendor.ru/shma.htm 